\title{
Landscapes and Mindscapes: Mapping Selfhood in a Chanson spirituelle of Marguerite de Navarre
}

\author{
JEFF KENDRICK \\ Virginia Military Institute
}

Les Chansons spirituelles de Marguerite de Navarre (1547) regorgent d'exemples de la façon dont la poétesse construit un soi varié et à plusieurs facettes à travers la confession, qui est à la fois une expérience sociale et intime. La découverte de soi de la poétesse se développe à partir de l'incapacité qu'ont les mots à exprimer ses expériences. Toutefois, la reine suggère qu'il est possible de s'approprier la parole universelle de Dieu pour son usage personnel. À travers cette appropriation, les chansons posent un défi aux notions d'individualité de la Renaissance, qu'elles soient prises d'un point de vue social ou individuel. En particulier, on montre comment les procédés rhétoriques préfigurent ce que plus tard les écrivains désigneront par "le moi fragmenté ». Les paysages ou leur absence sont un moyen d'articuler les aspects intérieurs et extérieurs de sa conception de l'individualité, puisque c'est à travers la représentation de paysages que Marguerite exprime clairement l'expérience de son monde intérieur et son monde extérieur. À travers l'observation des personnages de ses poèmes déambulant dans différentes géographies, se dégage un sentiment d'intériorité exprimé à travers l'espace physique et extérieur. De plus, la poétesse hésite visiblement à établir des limites claires entre son soi intérieur et le monde extérieur de l'expérience. Ces deux aspects entretiennent plutôt un dialogue constant. En personnalisant les paysages de sa poésie, Marguerite induit dans ses chansons un questionnement à propos de la relation entre le sujet littéraire et le soi. Finalement, elle se retrouve piégée entre la position humaniste de l'épanouissement et le devoir évangélique d'abnégation.

$\mathrm{M}$

arguerite de Navarre's longer devotional poetry and (generally) shorter Chansons spirituelles (published in the Marguerites de la marguerite des princesses [1547]) constitute a significant contribution to the early modern struggle with selfhood and subjectivity. Her poetry can be read as one individual's conception of the divine nature ${ }^{1}$ and she regularly structures her poems 
around a first-person subject position in order to delineate and elaborate the psychological entity she often terms her "soul." This delimitation of her soul and the accompanying details that clarify its position relative to the author underscore the texts' obsessions with subjectivity. Marguerite infuses her poetry with meditations about what it means to be both a literary subject and an individual who expresses herself through verse. Within the poems themselves, the queen recasts familiar topoi such as pastoral landscapes to embellish and clarify the idea of the soul. However, these techniques add to the polysemous nature of both selfhood and the texts themselves. Specifically, the way in which Marguerite personalizes landscapes within her poetry infuses the songs with questions regarding the relationship between the literary subject and the self. The place of the amorphous subject is undermined and divided as the tension between desire and death mount, revealing the poet's own apprehensions regarding her relationship to the other. Specifically, she is held hostage between the humanistic position of empowerment and the evangelical constraint of self-denial.

\section{Chansons spirituelles and evangelical selfhood}

In order to analyze the place of the individual within Marguerite's Chansons spirituelles, it is first necessary to establish the context in which they were written. The chanson spirituelle genre blossomed throughout the sixteenth century due to evangelicals and Protestants trying to avoid superficial and lavish music that, in their minds, characterized popular and ecclesiastical songs, respectively. John Calvin later specifically enumerated and denounced these excesses in his role as the secular authority in Geneva. ${ }^{3}$ Typically, the writer of a chanson spirituelle would take a popular secular song and keep the melody but change the lyrics to reflect a spiritualized understanding of God's love and grace and the believer's faith. Most importantly, the new text gave preeminence to God's Word. The principle of sola scriptura that pervaded all aspects of the evangelical's life required the language of man to be subject to God's Word. The resulting new song accordingly reflected the sinner's transformed nature and was suitable for the Reformed/evangelical Christian to sing in church and at home.

In this way, chansons spirituelles in general serve as metaphors for the evangelical understanding of the spiritual transformation that occurs in regeneration by grace. ${ }^{4}$ In an effort to promulgate this message, the group at Meaux 
that surrounded Marguerite's spiritual advisor, Guillaume Briçonnet, published such songs, and the authors were subsequently persecuted by the Parliament of Paris as early as $1525 .{ }^{5}$ Given the intensity of inquisitions surrounding any new songs, Catholic leaders apparently did not dismiss the importance of the chansons. The authorities passionately pursued the songwriters for promoting their new religion and threatening orthodoxy. ${ }^{6}$

Specifically, this persecution sought to counteract the emphasis on the individual nature of the soul that permeated the new songs. As writers intertwined theology, intimate devotional responses to God, and their personal interpretation of God's word, they carved out a space for self-expression and personal agency, and laid foundations for the psychological entity that moderns would eventually call the "self." The subsequent personalization of theological formulae and frameworks led to a Protestant poetry that, as Gary Ferguson notes, "focuses the attention of the reader on the lament of the sinner to the almost total exclusion of any consideration of God's mercy or the saving passion of Christ."

This individualized evangelical expression is quite different from a modern, post-Romantic understanding of personalization in which one's own particular feelings or reactions stress the uniqueness of the individual. Personalization for the evangelical is not a matter of effusive emanations describing a suffering that is distinct from all others'. Rather, as Protestant poetry develops, it exhibits anxiety about the fallen nature of humanity in general and the resulting implications for the individual soul's fate and eternal destiny. ${ }^{8}$ In particular, Marguerite de Navarre's later works (including the Chansons spirituelles) express a quintessential pessimism regarding the nature of humankind. ${ }^{9}$ This uncertainty results in a poetic expression that is concerned with and turned toward the individual as bearer of an insurmountable sin debt. The evangelical's expression of personhood vacillates between an optimistic confidence in God's grace extended to humanity through the work of Christ and a tortured restlessness concerning the extension of this general grace to the individual's soul.

The resulting inner anxiety leads to a concept of the self as either a slave to its own passions or as taking part in the divine nature that is externally imputed by Christ. The self is individualized only insofar as its relationship to an exterior construct-either sin or Christ-is realized. Self-definition is a result of describing where one falls in this dichotomy. Though couched in evangelical 
terminology, this dialogic nature falls nicely in line with what others posit concerning the necessity of reference points to any cohesive understanding of the self. For example, in his history of the self, Charles Taylor observes,

I am a self only in relation to certain interlocutors: in one way in relation to those conversation partners who are essential to my achieving selfdefinition; in another in relation to those who are now crucial to my continuing grasp of languages of self-understanding-and, of course, these classes may overlap. A self exists only within what I call "webs of interlocution." 10

Placing this idea in the context of justification and sanctification clarifies what this means for evangelical poets ${ }^{11}$ such as Marguerite de Navarre. Ehsan Ahmed has highlighted the shifting view of the self in Marguerite's Chansons spirituelles. ${ }^{12}$ According to his analysis, the soul in the queen's poetry strays from a "charitable self" whose essence is in the keeping of the (Mosaic) commandments. These laws, according to Augustine, push those who keep them to perform acts of charity and, thus, practically demonstrate union with God and with His followers. Ahmed maintains that as the Chansons develop, it is possible to observe a faith-based entity, free from the legal requirements laid down. This evangelical view of the self sees identification with Christ (and His body, the church) as contingent upon a loving relationship granted by God's sovereign grace as opposed to legalistic fulfillment of certain ordinances or sacraments. This tension saturates the Chansons spirituelles as Marguerite employs different rhetorical strategies to give voice to a self caught between the two viewpoints.

Such polyphonic techniques and tensions also find their influence in a more secular context: the poetry of Petrarch. As one of the most influential lyric poets on French writers in the Renaissance, Petrarch strongly impacted all modes of poetic expression with his approach to structure. William J. Kennedy remarks that the "Petrarchan speaker's rhetorical strategy of alternating and suspending contrarieties" creates a poetic expression that allows a "dialectical unity to evolve out of multiplicity." ${ }^{13}$ Though Petrarch's tension results primarily from the relationship between (implied) speaker and (intended) audience, the Italian poet's manipulation of ethos and pathos "generate[s] a field of contrasts, reversals, and antitheses"14 which are the hallmark of Marguerite's poetry as well. 
Marguerite, of course, adapts Petrarchan themes to religious use and often substitutes her soul and Christ as the two lovers in her texts. This reflects her evangelical attitude toward the individual's intimate relationship with Christ. The tension between speaker and addressee still remains, and she does not discard the ambiguity of the literary subject that characterizes the Petrarchan sonnet. ${ }^{15}$ In the same manner, her poetry tends to drift. It slips between voices and images in a way that encourages a constantly shifting perspective within the individual songs. For Marguerite, the question of identity - that is, who she is as an individual-is more a question of how she interacts with the world around her. As John Jefferies Martin recently stated, "Renaissance identities [...] were less about adopting a particular stance to the world than about the question of how different stances might affect one's relations to the world and, in particular, one's relation to other human beings." ${ }^{16}$ This in turn makes defining the self an elusive goal and reinforces the permutations Marguerite experiments with as the humanistic self-affirming author and the committed self-abjecting evangelical.

\section{Using poetry to negotiate spiritual tension}

Such conflict leads to a patchwork picture of the self in Marguerite's spiritual poetry as the author seeks to evoke and legitimize these competing influences. The Chansons spirituelles are replete with examples of how the poet uses language to construct a multi-faceted, variegated self through confession that is at once a social and internal experience. This confession projects a negative self-abstraction which in turn leads to a self-recognition as the poetic persona contemplates her own sinfulness. The soul more clearly delineates itself as it delves more deeply into its own sinfulness. Moving from more abstract to more concrete differentiations, Marguerite's songs perform the construction of the self as a product of unitive grace. According to Robert Cottrell's formulation in The Grammar of Silence, the poet finds herself struggling with words to give shape to this amorphous creature that emerges from her contemplations of human sinfulness. ${ }^{17}$ Marguerite's self-discovery develops from the fact that words are incapable of expressing her experiences. Theologically, this is linked to Luther's earlier understanding of the Scriptures as speaking to the individual soul on a personal level. Although nothing new can be said, the individual must take what has already been spoken by God in His word and interpret it 
and apply it within the context of his or her personal experience. Marguerite suggests that it is possible to individualize the universal word of God by appropriating it for her own uses. Through it, she creates and justifies her poetic persona's existence and challenges notions of individuality in the Renaissance as either strictly socially or individually constructed.

She does so by dislocating the notions of selfhood and literary subjectivity in several ways. First, she uses personified abstractions. Marguerite takes generalized ideas of love, for instance, and personifies them in order to create a paradoxical nearness with and separation from her reader. In particular, I am interested in demonstrating how these rhetorical manipulations anticipate and prefigure what later writers will call the fragmented self. The elusive nature of the self permeates the Chansons spirituelles and opens the door for a more detailed investigation of the self by later authors such as Montaigne, highlighting the importance of these poems in French literary development.

Insisting on this dual nature of the self, Marguerite's poetry also proposes landscapes as a means to integrate these two aspects of her conception of the individual, for it is through the representation of landscapes that Marguerite clearly communicates the experience of her inner world and its relationship to the larger environment around her. As one observes various speakers in her poems wandering through different geographies, a sense of interiority as expressed through the exterior, physical environment emerges. At the same time, the poet clearly hesitates to establish firm boundaries between her inner self and the external world of experience. The two are in constant dialogue with each other throughout the poems. The Queen of Navarre's concern regarding the interaction between these two aspects of her individuality and its relationship to the material world stems from the influence of Neoplatonism which holds that the ability to represent one's physical environs recalls not only the fact that humans bear God's image; it also reflected humanity's creative power. One of the most significant influences in Marguerite's aesthetic is the Italian Neoplatonist Marsilio Ficino, who claimed that when humans write about the stars and the planets, they simply recreate them with different materials. ${ }^{18}$

Of course, Marguerite is not concerned with representing heavenly bodies in orbit. She does, however, write a lengthy song set in the mountains and spends many lines mapping out the pastoral landscapes around her. As with the other literary devices she employs, the poet takes the pastoral genre and makes it her 
own to exhibit and examine herself. The mountainous wilderness of Marguerite de Navarre's poetry, as tradition would dictate, is a place where lovers meet to enjoy ecstatic union. The participants in this love story, however, are not lusty shepherds seeking fulfillment at the expense of some naïve shepherdess upon a verdant hill. Instead, the poem tells the story of the spiritual journey of a wandering vagrant and calls attention to the overwhelming presence of the lover that makes any desolate landscape seem inviting.

In order to demonstrate how Marguerite takes the genre and reinvigorates it with her own voice, it is first necessary to define it. The term "pastoral" eludes quick and straightforward classification. However, it is basically comprised of bucolic images often evoked from the past or some idealized version thereof. Typical characters include shepherds and shepherdesses (and sometimes nobles trying to take advantage of peasants). Though there are many variations on the pastoral genre, it has long been held that its "method or perspective" is one that idealizes certain aspects of rural landscapes and highlights the beauty and transformational powers of the countryside. ${ }^{19}$ The ambience of the rural surroundings often calms and liberates the inhabitants and those who travel through the open spaces, bringing them into a more natural state. This welldocumented phenomenon of affective topography in which a literary space takes on characteristics of the subject's actual or desired psychological state corresponds to the human need to map out or understand what is transpiring in the human psyche. ${ }^{20}$

Tom Conley reaffirms this connection between early modern French poetry and the geographic environment in his book An Errant Eye, wherein he states that "the poet is like a cartographer insofar as it is his or her task to describe the world by mixing images, visual designs, and both aural and optical traits of language." ${ }^{21}$ He goes on to point specifically to the Marguerites de la Marguerite des princesses (among other works) as a work in which "locale is crucial to the grounding vision and design"22 and links self-study and topography in the works of contemporaries of the queen such as Maurice Scève and later writers including Ronsard, Du Bellay, and Montaigne.

According to an engaging article by Rosanna Gorris Camos, this desire to find analogues between oneself and one's surroundings often plays itself out in literary descriptions of mountains. Particularly, she argues that the relationship between mountainous scenery and mental anguish has allowed authors to explore complex dialectics such as that between desire and fear or between death 
and silence. ${ }^{23}$ At once inspiring creativity and personal expression, mountains can also be full of danger and drive those who choose to brave them into a paralyzed silence. Gorris Camos comments that no matter what one's reaction to the foreboding heights, they have long been considered "un lieu fort de l'expérience humaine, mystérieux et provocatoire, lieu d'ascèse et d'initiation, de mort et de naissance, d'épreuves et de défis extrêmes qui rapprochent l'homme de la divinité et de lui-même." (... a stronghold of human experience, mysterious and provocative, a place of asceticism and initiation, of death and birth, of testings and intense obstacles that brings a person closer to the divine and to a deeper understanding of herself. ${ }^{24}$ Biblical authors have treated the mountains as both a place of refuge (David's consistent metaphor for divine protection being a "rock") and frightful judgment (God's law and wrath being demonstrated through thunder and lightning as well as threats of death and damnation to any who would dare approach Mount Sinai). Speaking of the development of mountain imagery through the sixteenth century, Yvonne Bellenger has argued that at "[...] un certain moment, vers la fin du XVIe siècle, ils ont changé de modèles pour se mettre à aimer la montagne et ses paysages." (...sometime, near the end of the sixteenth century, they [authors] changed models and began to love mountains and their landscapes. $)^{25}$ I argue below that Marguerite's unique blending of the horror and glory of mountain experiences in the Chansons spirituelles represents a significant movement toward that "moment."

Full of contradiction and interdiction, mountains make the ideal setting for Marguerite's pastoral poetry. As seen above, the notion Marguerite has of the self in these songs is dialectic and multi-faceted. It is unstable, and the poetic voice in many of the poems is uncertain of where her "soul" stands from one moment to the next. Try as she might to get a handle on her relationship to the world around her and to the Divine Other, she always seems to be incapable of creating a fixed self-image. One of her longer Chansons tells the story of a wanderer who finds herself on a mountain. The subject of the poem, known to the teller of her story as la malheureuse (the unfortunate one), inhabits a bleak landscape along with birds of prey, other beasts, and harbingers of death and misfortune. ${ }^{26}$

Marguerite maps out the inner turmoil she experiences by means of this threatening mountainous terrain. As Gorris Comos has noted, "Les montaignes sont le point final d'un processus qui conduit l'homme au sommet de son 
itinéraire existential, de son ascension, difficile mais nécessaire." (Mountains are the final destination of a process that leads a person the summit of her existential journey, of her ascent, difficult but necessary. $)^{27}$ They are the place of self-knowledge and understanding as well as obstacles to the same. In this poem, the speaker's spiritual struggle is played out in the third person as she describes the perilous journey of a vagrant wanderer over the rugged and barren landscape. The mountain is, of course, a religious symbol. It is a place where ultimately the protagonist draws near to God and moves from being unhappy to spiritually fulfilled in the Divine Presence. It would be foolish to discard this interpretation. Alongside that hermeneutic axis, the poem also presents an attempt to describe the interior struggle the poet is having with her "self" as an author desiring to write. The mountain simultaneously represents the place of that struggle and the struggle itself. In addition to seeing Marguerite's landscape as a mapping out a way to God, it is possible to interpret it as a map of her inner self (both actual and idealized) as she struggles with the notions of authority, subjectivity, and identity. In this way, Marguerite's work suggests another step toward modern ideas of perspective and subjective authority.

An unnamed narrator serves as the guide through this unforgiving landscape, but her perspective is not univocal. Instead, she presents to the reader many different aspects of her interior world, reflecting the uncertainty she experiences as an author and as a believer in the midst of shifting religious waves.

She begins by inviting the reader to join her as she searches for the malheureuse. She is not the only one looking for this poor wanderer, for she quickly relates that "tous ennuis" (all worries) are also in pursuit. The poem's narrator quickly demonstrates her intimate knowledge of the psychological and affective goings on of the unhappy pilgrim when she says she desires no good and does not want even to draw near to joy. With such understanding, the speaker shares a god-like power to gaze into the thoughts and desires of the one she describes, and it is clear that she is presenting more than just a simple story of someone's mountain trip. Furthermore, it seems that the narrator has asked a question she knows the answer to, for in the next stanza, she tells the reader that the object of her inquiry is not "en la plaine / De propre delectation, / Elle s'en va en la Montaigne / De toutte tribulation" (in the plain / Of her own pleasure, / She goes to the Mountains / Of all tribulation, 5-9). Indeed, she unveils an intimate knowledge of what is (and is not) on these mountains in the lines that follow. For example, she testifies to the absence of others on the mountain as well as 
to the nature of the area's flora and fauna in lines 13-20 and 25-35, indicating that she has explored the region in order to speak authoritatively to what is and is not there.

Even from the beginning, the narrator orients the landscape around the malheureuse by relating the experience of the mountains from her point of view. The subject of the poem moves fearfully about the physical environment the poem describes. She is running, leaving, coming, going. Verbs of motion dominate the poem's opening. For example, forms of venir (to come), chercher (to look for), approcher (to approach), s'en aller (to go away), and fuir (to flee) all appear in the first twelve lines. It is a dizzying experience to follow the erratic movements of this object of the narrator's search. The blurred vision caused by the restlessness of the peripatetic wanderer results in an incomplete and fragmented picture of the mountain. It becomes a place of near raving, a void, empty of any sign of order or purpose. The obscurity of the mountain also leaves the reader with limited perspective and a sense of mystery as to the exact nature of this imposing ridge. The emphasis on the psychological processes at work in the main character pulls the reader to move from a solely exterior focus to an interior investigation. Using what is visible to point to what is unseen, the poem infuses the mountain with symbolic meaning. Read as a map of her emotional and psychological processes, these first notions of surroundings come through a jostled, displaced point of view and emphasize the malheureuse's inherent instability as well as her inability to move purposefully.

Yet even in this nomadism, there is a sense of direction. The poet is clear that the wanderer is fleeing her own satisfaction. She turns away from any experience that would bring her joy. As mentioned earlier, she is not to be found "en la plaine / De propre delectation" (5-6). This flat ground where she could find peace and where her journey would not be so strenuous stands in sharp contrast to the rugged "montaigne / De toutte tribulation" in the following two lines. The malheureuse deliberately chooses to roam these cliffs and seemingly rejects the calm of pleasure and delight.

The voice describing these mountains does not paint a precise picture of what they look like. Rather, the reader is given a sampling of what occupies or is absent from the landscape. The narrator provides her impression of the environment through the use of images and sounds or silences that make up the fundamental essence of what the malheureuse is experiencing on the sterile peak. Qualities that both delineate and pixelate the countryside add clarity and 
ambiguity to the scene being described. For example, highlighting the wanderer's solitude in this desolate wasteland, there is neither "homme ny femme" (man nor woman) occupying this empty space (9). She has roamed outside the boundaries of human habitation. There is no one to comfort her and no one who can understand her. The reader senses the loneliness of the situation, and this is highlighted by the fact that human beings do not want to live on this mountain; yet she chooses to be here. She sets herself apart by desiring to be "en ce lieu sainct" (in this holy place or in this temple, 11). Away from the known world, she enters a holy (set apart) place, void of humanity and full of holiness. Paradoxically, she knows where she is (away from all others) and is also completely in the dark as to her location and what awaits her.

Apart from humanity, the unhappy vagrant has no point of reference upon which to fix her emotions, just as the narrator has no geographical landmarks upon which to fix her description. Consequently, it seems as though the space the malheureuse inhabits exceeds the narrator's ability to describe. The description then must not be limited to simple lines, measurements, and other physical landmarks. The narrator thus begins to catalogue the different animals conspicuously missing from the surroundings. By juxtaposing birds typically associated with love and sensual pleasure in traditional pastoral poetry and avian harbingers of death and decay that dominate this bleak landscape, the poem modifies its rhetorical model. ${ }^{28}$ What comes out of this is a mountain that would normally promise life, love, and happiness dominated by a darker range of mortality, annihilation, and decomposition. This is the "lieu sainct."

As has been pointed out, it is not unusual for Marguerite to evoke mountains as places where such odd pairings are common. Paula Sommers has commented on the ascending and descending movement in many of Marguerite's devotional poems. ${ }^{29}$ The heights Sommers describes are encounters with God. Marguerite's meditations do not rest upon the lowliness of humanity. Her eyes gaze upward to contemplate the grandeur of the Divine. In the Heptaméron, the faithful escape the floods by seeking refuge in an abbey on a hill. Additionally, it has also been demonstrated that elsewhere mountains for the Queen of Navarre were also frightful places and were used to allude to the "mystérieux secrets de l'homme et de la femme" (mysterious secrets of men and women). ${ }^{30}$ Marguerite in Les Prisons descends to ponder the darker side of humanity, while the Heptaméron, of course, is full of stories that highlight human tendencies toward pride, sensuality, and deceitfulness. 
It is not surprising that this mountain is a mixture of holiness and putrefaction. The wanderer is trapped between two worlds as she struggles with her nature and how to interact with the purity that God represents and that she desires. The mountain is a threatening place where omens of death wait around every corner, but it is also a refuge of solitude to which one can withdraw from the exterior world of interaction with others. On the heights, the malheureuse is free to consider her for intérieur, and the reader who follows her there experiences the haunting sounds that imprison her innermost being. The mountain (and the world it contains) allows the poet to experience herself afresh and to know herself more completely than she did before.

These images of death and dying are also opposed to the creativity that the poem itself represents. Marguerite juxtaposes decay and burgeoning spiritual and artistic life. The voice that the malheureuse finds in the text emerges from a landscape of death, and the poem is birthed in a tension-filled space inhabited by antagonistic forces of destruction and creation. In effect, the narrator follows the vagrant and describes her death and rebirth. The mountain is the place in which her desire and her death meet, where her "self" is conceived. Creating a world inhabited by images that signify what she describes, and following an obscure path, the malheureuse arrives at a place where she is reborn herself and able to proclaim that which she was so unwilling to desire at the beginning of the chanson.

The journey towards this self-consciousness is taken up in the first lines. The fact that the narrator refuses to name death at the opening of the poem and chooses to avoid direct discourse allows an interior interpretation of the text. Through the eyes of the presenter, the reader sees threatening birds fly in and predict evil for the future (17-20). The landscape takes on the eerie melancholic cries of bats and other creatures of the night that are opposed to the pleasure of laughter (21-23). The movement away from describing the mountain itself reveals the true object of the narrator's depiction. She does not refer to the rocks and ridges that compose and outline the landscape. Instead, she focuses on the inhabitants of the surroundings and the sounds and sights the unhappy traveller experiences. What is missing becomes just as important as what is present. The experience of the protagonist takes centre stage, and the reader is pushed to more interior concerns. The symbolism of the landscape's inhabitants draws attention to the words being used to describe the mountain and the images they evoke. 
The contrasts between absence and presence continue throughout the poem and bring the reader into a cycle of non-being and being that reflects the interiorization of the mountain landscape. The narrator consistently juxtaposes opposites in the stanzas that make up the remainder of the poem. From the two types of birds already noted to the contrast between domesticated and wild animals (25-32), fruitful plants, blossoming flowers, fertile plains, and the barren wasteland (33-44), folly and wisdom (34-52) and so on, the poem becomes more about the inversion and enumeration of images. The scene is thus transformed from a physical description of a mountain, a natural landscape, to an imaginary place that is inside the mind of the malheureuse. The pictures the narrator lays before the reader are the objects and the subjects of her suffering and her writing.

This intensifies the sense of competing pressures on this mountain and in the mind of the wanderer. As the narrator catalogues each missing image of life and opposes it to a sombre image of death and sterility, the landscape becomes the site of an internal poetic battle between the writer's desire to create and her drive to remove herself and her voice from her work. The alternating visions of the surroundings emulate the pulse of competing drives within the malheureuse's psyche. The mountain seems to mimic the exchange going on inside her mind-the swelling as ideas come to her and the repression as she yearns to write herself out of her poetry.

\section{Writing in the mountains}

The narrator makes the reader aware that she is engaged in artifice. The specific mention of the absence of "ouvraiges" (works of art) in line 57 and "tableau" and "paincture" (paintings) in line 62 draws a distinction between the description of the landscape and the actual meaning behind the description and focuses the reader's attention on the words themselves. They are painting a picture in the reader's mind, but this picture does not exist in the malheureuse's world. There are no paintings or works of art that cause the inhabitants of this mountain to contemplate a Neoplatonic echo of "le bon et beau" (64). The text becomes a sign of something else, an indication that the reader should look beyond the literal meaning of the words to discover the true object being described in such detail. 
That Marguerite also has in mind the writing process is evident in the poem when the narrator reveals that on the mountain

Là ne $\mathrm{cr}[\mathrm{o}]$ ist papier, encre ou plume

Pour escripre ce qu'elle veult,

Ny livre, livret ny volume;

Toutesfois elle ne s'en deult. $(69-72)^{31}$

These verses highlight (more than anywhere else in the song) that this poem must be read as a writer's interior struggle with the writing process. As Robert Cottrell has pointed out, the Chansons spirituelles all point to " $t \mathrm{t}]$ he conflict between composing autonomous texts while maintaining a Christian submission to authority [that] informs the problematic of writing in Marguerite's poetry and reflects a tension between love for the creature and love for the Creator." ${ }^{32}$ Furthermore, he notes that "Marguerite's poetry tends always toward a deconstruction of the visual, the concrete, the fleshy. Her landscapes are not of the outer world but of the inner world. The ultimate décor in all her poetry is the human heart." ${ }^{33} \mathrm{He}$ concludes that the Queen of Navarre desires to write herself out of her poems in order to allow the Word of God to speak clearly through her. In this poem, the failure of writing silence takes centre stage through the narration of the malheureuse's unfortunate vagabonding. The images of the writer's tools and the product of the writing process reorient the passage and allow not only a spiritual interpretation but this secular one as well. The poem becomes a text about a woman who cannot compose her own text.

This internal struggle between the author's desire to write and the necessary death to self problematizes the reader's understanding of and reaction to the poem. On one level, this internal struggle simplifies the description. If the reader accepts the proposed interpretation, it would follow from Cottrell's analysis that the text would finish as a "linguistic cenotaph" in which "Marguerite refuses to tell a story and, thus, present a forward-moving narrative." ${ }^{34}$ One would expect to see a malheureuse at the end of the poem who resembles to a large extent the one encountered at the beginning. This is not, however, the case. She has seemingly advanced, for the narrator concludes in the poem's final stanza: 
Or est la malheureuse heureuse,

Et son malheur faict très heureux,

Puisqu'elle [est] parfaicte amoureuse

De son trespas faict amoureulx. $(161-64)^{35}$

She has moved through death into life. Her words have taken on a life for themselves, and she is able to create a poem that, as Michèle Clément notes, recalls the linguistic acrobatics of the grands rhétoriqueurs. ${ }^{36}$ Linguistically speaking, she is more alive and has more of a voice than she did at the start. She has not succeeded in writing silence. On the contrary, she has given herself more authority than before.

\section{Pleasure in the mountains}

Furthermore, the now happy malheureuse (or rather the one recounting her story) has created a world of pleasure and aesthetic attraction. ${ }^{37}$ The description of the landscape in this poem produces a sensation of pleasure that foreshadows what Ullrich Langer has pointed out is found in later Renaissance poets Joachim Du Bellay and Pierre de Ronsard. The delight this mountain offers the malheureuse vacillates and contradicts itself by continually changing form. As Langer states, "The poetry of landscape is not, however, simply a representation of variety, that is, of varied features of a coherent space, but puts forth a certain relationship of the poet and reader to variety." ${ }^{38} \mathrm{He}$ summarizes the idea of pleasure in the Renaissance as "doing freely what you do best." ${ }^{39}$ In his conclusion, Langer notes that both Du Bellay and Ronsard represent pleasure as being able to move unimpeded through one's surroundings. ${ }^{40}$

I would argue that Marguerite de Navarre's description of the mountain in this poem is also a source of enjoyment, but one that finds itself in the variation between desire and death or activity and constraint rather than in the depiction of unrestrained movement. The landscape offers both a hiding place and a place where both Christ and the narrator track and find the malheureuse. This song is about an ascetic self-denial of instant pleasure that results in spiritual union and lasting enjoyment in the end. Thus, the poem vacillates between images of fertility and life and sterility and death on many levels. Also indicative of this type of variation is the emphasis on absence and presence. Nearly every stanza 
(especially in the poem's opening), presents a pulsating view of the mountain in dizzying alternation.

The protagonist finds her fulfillment, however, not in the freedom of her mobility but in embracing the suffering associated with death. Opposed to the jostling image of the wanderer at the start of the poem, line 120 presents a lover full of joy who "se veult arrester" (wants to stop) and spend time with the object of her affections. This woman chooses banishment from the world and isolation in order to enjoy the Creator (125-44); she "ayme sa melencolie / Et ne refuse nul tourment" (loves her melancholy / And refuses no torment, 121-22). Several stanzas just before the end of the poem demonstrate the extent to which she changes and the pleasure she finds in ceasing to move on her own initiative. Speaking of herself as the "uncomforted" one, she describes how Christ comforts her, changes what she saw as torments into pleasures, and brings her back to life:

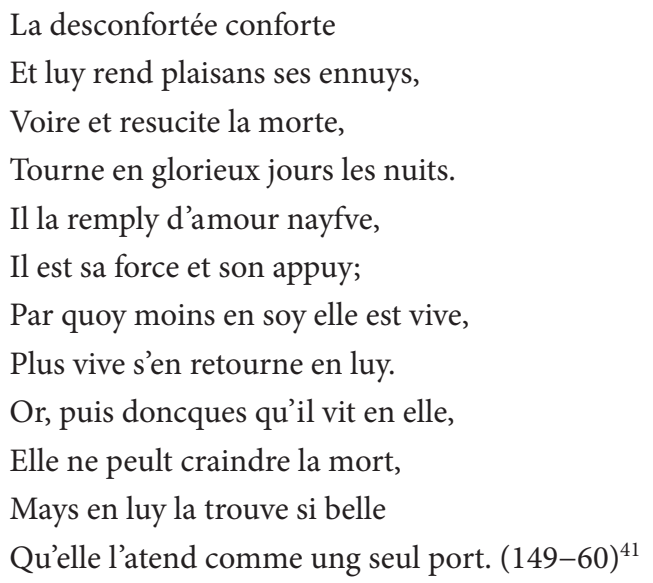

The malheureuse who is thus transformed into lover is last seen waiting patiently for death. Having experienced and embraced it, she finds herself paradoxically more alive. Her happiness is a result of her patience and her immobility. This immobility is the final resolution of all of her moving about and is how she resolves her tendency to wander. Her relationship with God has made "plaisans" (pleasing) her "ennuys" (worries). Instead of seeking to free herself from her seemingly paralyzed state, she turns her gaze upward away from her environment 
Car eslevant au ciel la teste

En contemplant leur [beasts and men] createur,

De l'ouvraige elle faict la feste,

Puisqu'il donne gloire au faicteur. $(141-44)^{42}$

Her surroundings are not her means of experiencing pleasure. Rather, it is the restful cessation of movement that results in a contemplative state of bliss. Later poets will refuse this rest and develop wandering and the accompanying variety as the actual source of pleasure, but Marguerite's journey and destination anticipate the joy that that these later poets will expand.

The mountain landscape is what drives a consideration of the possible alternatives to her current existence. It is also a symbol of her spiritual state of anguish and an obstacle to overcome in her search for freedom and self-expression. Death and desire are linked in a dialectic cycle in which one inspires and silences the other. Marguerite's description of the environment is inspired by her inner dialogue and points to the unheard by means of the seen and the unseen. Just as the malheureuse must navigate the treacherous peaks and crevices of the mountain, the writer must negotiate spiritual and authorial tension as she explores her "self." In many of Marguerite's Chansons it is the "soul" who takes centre stage. The narrator of the poem steps outside of herself to engage her soul in dialogue or to examine alternating idealized and realistic visions of her soul. Manipulating nature and making a map of her unseen psychological "geography" is another literary tool Marguerite uses to attempt to formulate a poetic vision of the fragmented self.

\section{Conclusion}

Marguerite's use of landscapes in this poem represents an attempt to relate her inner experience to her experience in the world and problematizes our understanding of subjectivity in the poems by leaving the tension between death to self and desire to express oneself unresolved. The speaker in this poem cautiously follows and maps out the demise and rebirth of the malheureuse. This death, burial, and resurrection take place in a spatial creation that the speaker establishes through her description of the mountain landscape. Furthermore, the poem itself is the setting and the outworking of the poet's textual death and rebirth. Understanding this complex relationship between desire and death 
in Marguerite's spiritual poetry can also inform the reading of her prose to the extent that "[d]esire motivates the act of narration in the Heptaméron, but one must also take into account the relationship between desire and death in order to get a more complete understanding of narrative motivation in the short stories. Death is both the source and the end of desire." ${ }^{43}$ Additionally, these unanswered questions will serve as the basis for later investigations by Montaigne among others. In his introduction to the Essais, Alexandre Micha notes that Montaigne is "[...] un homme qui a voulu se déchiffrer pour élaborer une sagesse personnelle, à la fois par expérience, par la méditation et par la lecture" (a man who tried to understand himself in order to develop a personal worldview through wisdom, meditation, and reading) but who ends up describing a "univers intérieur, mouvant et inconsistant" (an interior universe, moving and inconsistent). ${ }^{44}$ The impossible dream of elaborating a stable self leads Montaigne to accept a vision of the self that he calls "l'irrésolution." The same could be said of Marguerite's poetic self. Ironically, the Queen of Navarre, though her Heptaméron was criticized by Montaigne as an example of why women should not engage in theology, in her Chansons spirituelles actually prefigures the same self-investigation that would come to characterize, not only Montaigne's own writing, but much of modern French literature as well.

\section{Notes}

* All translations in this essay, except where otherwise stated, are mine.

1. Paula Sommers, Celestial Ladders (Geneva: Droz, 1989).

2. Many of Navarre's Chansons spirituelles are "narrated" by the soul. This entity often takes on properties characteristic of the modern understanding of the self. Given the emergent understanding of selfhood among her contemporaries, the soul incorporates the psychological traits now associated with the self.

3. Cynthia J. Brown, Poets, Patrons and Printers: Crisis of Authority in Late Medieval France (Ithaca: Cornell University Press, 1995), p. 145.

4. Though Protestants stressed that man remained a sinner even after salvation, they taught that the Spirit of Christ came to dwell in the believer's heart, thus regenerating him or her with Christ's life.

5. Brown, p. 147.

6. Brown, p. 148. 
7. Gary Ferguson, Mirroring Belief: Marguerite de Navarre's Devotional Poetry (Edinburgh: Edinburgh University Press, 1992), p. 7.

8. Ferguson, p. 8.

9. Ferguson, p. 42.

10. Charles Taylor, Sources of the Self: The Making of Modern Identity (Cambridge: Harvard University Press, 1989), p. 36.

11. I refer to Marguerite as a poet, though songwriter would be more appropriate in this context. For convenience sake, I use the terms "poem," "song," and "chanson" interchangeably.

12. In this chapter, Ahmed fits the Chansons spirituelles between Marot and Ronsard as a pivotal work in the renovation of the song form in the French Renaissance. See Ehsan Ahmed, The Law and the Song: Hebraic, Christian, and Pagan Revivals in Sixteenth-century France (Birmingham: Summa, 1997), pp. 69-93.

13. William J. Kennedy, Rhetorical Norms in Renaissance Literature (New Haven: Yale University Press, 1978), p. 20.

14. Kennedy, p. 22.

15. Kennedy, p. 27.

16. John Jefferies Martin, Myths of Renaissance Individualism (Hampshire: Palgrave Macmillan, 2004), p. 14.

17. Robert Cottrell's influential book was among the first to shed light on the neglected Chansons spirituelles and Marguerite's other devotional poetry: see The Grammar of Silence: A Reading of Marguerite de Navarre's Poetry (Washington: The Catholic University Press, 1986). Cottrell's work focuses on the mystical aspects of the queen's spirituality, while I will be highlighting the rhetorical structures Navarre employs to simultaneously differentiate and unify herself as poet and poetic subject.

18. Marsilio Ficino, Platonic Theology, trans. Josephine I. Burroughs, Journal of the History of Ideas 5 (1944), p. 235.

19. For a detailed study of the pastoral genre from its Roman beginnings see Eleanor Leach, Virgil's Ecologues: Landscapes of Experience (Itacha: Cornell University Press, 1974).

20. Several studies have demonstrated the early modern fascination with maps and geography and their correlation with contemporary conceptions of the human psyche. See, for example, Michel Chevalier, ed., La Littérature dans tous ses espaces (Paris: CNRS, 1993), and Taun Yi Fu, Topophilia: A Study of Environmental Perception, Attitudes and Values (New York: Columbia University Press, 1990). 
21. Tom Conley, An Errant Eye (Minneapolis: University of Minnesota Press, 2011), p. 3.

22. Conley, p. 19.

23. Rosanna Gorris Camos, "Ses monts trez haultz haulsent notre desir': Marguerite de Navarre, Peletier du Mans poètes de la montagne," in Nature et paysages: l'émergence d'une nouvelle subjectivité à la Renaissance, ed. Dominique de Courcelles (Paris: École des chartes, 2006), pp. 151-77.

24. Gorris Camos, p. 154.

25. Yvonne Bellenger, "Les Paysages de montagne: L'évolution des descriptions du début à la fin du XVI siècle," in Le Paysage à la Renaissance, ed. Yves Giraud (Fribourg: Editions Universitaires Friboug Suisse, 1988), p. 128.

26. In this paper, I refer to Chanson 34 written by Marguerite to be sung to "Avezvous vu La Peronnelle." All citations and references to the song are from Michèle Clément's excellent edition of the Chansons spirituelles. Michèle Clément, ed. Oeuvres completes, Vol. 9: La Complainte pour un detenu prisonnier et les Chansons spirituelles. By Marguerite de Navarre (Paris: Champion, 2001).

27. Gorris Camos, p. 155.

28. Nightingale, lark, starling, magpie, jays, and parrots, for example, are typical in medieval pastoral poems. They signify and sing of the (secret) meetings of lovers. The owl, night birds, and ravens that inhabit the space in this poem speak, too, of the secrecy of night, but they connote a more negative aspect of death and dying that is generally absent from the verdant pastures of the established generic protocol.

29. Sommers, passim.

30. Bellenger, p. 160.

31. There grows not paper, ink, nor pen

To write what she wants,

Neither book booklet nor larger volume;

Nevertheless, she does not lament over this.

32. Cottrell, p. 307.

33. Cottrell, p. 236.

34. For Cottrell's eloquent discussion on the idea of Marguerite's poems as a linguistic coffin, see pp. 213-19.

35. Now the unhappy one is happy

And her misfortune is made happy

For she is perfectly in love 
With her death [which has been] made lovely.

36. Clément, Notes, p. 228.

37. See Ullrich Langer's recent article, "Pleasure as Unconstrained Movement in Renaissance Literary Aesthetics," French Studies 64, no. 1 (2010), pp. 13-25. As I will demonstrate, Marguerite's poetics differs slightly from, but anticipates, that which Langer finds present in Du Bellay's and Ronsard's poetry.

38. Langer, p. 13.

39. Langer, p. 16.

40. Langer, p. 25.

41. [God] comforts the uncomforted one

And makes her worries pleasing,

Verily and revives the dead,

Makes nights and days glorious.

He fills her with a naïve love,

He is her strength and her help;

That is why the less she lives for (or in) herself,

The more alive she finds herself in him.

Now, since therefore he lives in her,

She cannot fear death,

But in him finds it so beautiful

That she waits for it as for a singular harbour.

42. For raising her head to the heavens,

While contemplating their creator,

She celebrates the handiwork,

Because it gives glory to its maker.

43. Richard Regosin, "Death's Desire: Sensuality and Spirituality in Marguerite de Navarre's Heptaméron," MLN 116, no. 4 (2001), pp. 770-71.

44. Montaigne, "Introduction," in Essais: Livre I (Paris: Garnier, 1969), pp. 12, 16. 
